\title{
Tissue expression and subcellular localization of the pro-survival molecule Bcl-w
}

\author{
LA O'Reilly ${ }^{1}$, C Print ${ }^{1,2}$, G Hausmann ${ }^{1}, \mathrm{~K}_{\text {Moriishi }}{ }^{1,3}, \mathrm{~S} \mathrm{Cory}^{1}$, \\ DCS Huang ${ }^{1}$ and A Strasser ${ }^{*, 1}$ \\ 1 The Walter and Eliza Hall Institute, Melbourne, Australia \\ ${ }^{2}$ Current address: Department of Pathology, University of Cambridge, \\ Cambridge, UK \\ ${ }^{3}$ Current address: Department of Veterinary Science, National Institute of \\ Infectious Diseases, Tokyo, Japan \\ * Corresponding author: A Strasser, The Walter and Hall Institute of Medical \\ Research, Post Office Royal Melbourne Hospital, Victoria 3050, Australia \\ Tel: +61-3-9345-2555; Fax: +61-3-9347-0852; E-mail: strasser@wehi.edu.au
}

Received 3.11.00; revised 21.12.00; accepted 21.12.00

Edited by G Melino

\begin{abstract}
Anti-apoptotic members of the Bcl-2 family, such as Bcl-w, maintain cell viability by preventing the activation of the cell death effectors, the caspases. Gene targeting experiments in mice have demonstrated that $\mathrm{BCl}-\mathrm{w}$ is required for spermatogenesis and for survival of damaged epithelial cells in the gut. $\mathrm{Bcl}-\mathrm{w}$ is, however, dispensable for physiological cell death in other tissues. Here we report on the analysis of Bcl-w protein expression using a panel of novel monoclonal antibodies. Bcl$w$ is found in a diverse range of tissues including colon, brain and testes. A survey of transformed cell lines and purified hematopoietic cells demonstrated that Bcl-w is expressed in cells of myeloid, lymphoid and epithelial origin. Subcellular fractionation and confocal laser scanning microscopy demonstrated that Bcl-w protein is associated with intracellular membranes. The implications of these results are discussed in the context of the phenotype of Bcl-w-null mice and recent data that suggest that $\mathrm{Bcl}-\mathrm{w}$ may play a role in colon carcinogenesis. Cell Death and Differentiation (2001) 8, 486494.
\end{abstract}

Keywords: apoptosis; Bcl-w; spermatogenesis; monoclonal antibody

\section{Introduction}

Apoptotic cell death plays a critical role in moulding embryonic tissues, in regulating cell turnover and in defending the host against pathogens. ${ }^{1,2}$ Failure of cells to undergo appropriate apoptosis can lead to cellular transformation ${ }^{3}$ or autoimmunity, ${ }^{4,5}$ whereas premature apoptosis of long-lived cells has been implicated in the pathology of degenerative disorders. ${ }^{6}$

Cell death can be induced under a variety of physiological and experimentally induced conditions. These cytotoxic stimuli can activate distinct signaling pathways that converge upon a common cell death effector machinery driven by cysteine proteases (caspases). Certain caspases ('initiator caspases') are activated through autocatalytic processing, with the help of adapter proteins, while others ('effector caspases') are activated by already active caspases. ${ }^{7,8}$

Members of the $\mathrm{Bcl}-2$ protein family are key regulators of cell death. ${ }^{9}$ Mammalian $\mathrm{Bcl}-2$ and its closest relatives, such as $\mathrm{Bcl}-\mathrm{x}_{\mathrm{L}}$ and $\mathrm{Bcl}-\mathrm{w}$, are thought to prevent caspase activation by inhibiting adapter proteins, either by direct interaction or by blocking release of apoptogenic co-factors from mitochondria. ${ }^{8,10}$ The pro-survival function of the Bcl2-like anti-apoptotic sub-family can be inhibited by the relatively closely related Bax sub-family, and also by distant relatives, such as Bik (Nbk) and Bim (Bod), which share only the short $\mathrm{BH} 3$ domain. ${ }^{9}$ The pro-apoptotic proteins bind to $\mathrm{Bcl}-2$ or its functional homologs via their $\mathrm{BH} 3$ domain ${ }^{11}$ and it is believed this initiates the cell death effector machinery. 8,9

$\mathrm{Bcl}-\mathrm{w}$ was originally cloned by virtue of its sequence homology to other Bcl-2 family members. ${ }^{12}$ As with $\mathrm{Bcl}-2$ and $\mathrm{Bcl}-\mathrm{x}_{\mathrm{L}}, \mathrm{Bcl}-\mathrm{w}$ overexpression renders cells refractory to cell death induced by many death stimuli, but not that triggered by members of the TNF-R family that have a 'death domain' (e.g. TNF-R1 or Fas). ${ }^{12,13}$ Gene targeting experiments in mice have revealed that $\mathrm{Bcl}-\mathrm{w}$ is essential for spermatogenesis - mutant males were sterile due to a gradual depletion of all stages of germ cells. ${ }^{14,15} \mathrm{Bcl}-\mathrm{w}$ appeared to be dispensable for normal development and functioning of all other organs, presumably because these also expressed other pro-survival Bcl-2 family members.

Northern blot analysis had shown that $b c l-w$ mRNA is expressed in diverse tissues and in many myeloid cell lines. ${ }^{12}$ To investigate the expression of Bcl-w protein, we have now generated specific monoclonal antibodies (mAb). $\mathrm{Bcl}-\mathrm{w}$ was found to be widely expressed in normal mouse tissues, particularly in the brain, spinal cord, colon, testes, most hematopoietic cells and fibroblasts. Bcl-w was also found in a variety of transformed murine and human cell lines of epithelial origin. Subcellular fractionation and confocal laser scanning microscopy revealed Bcl-w on cytoplasmic membranes, such as the nuclear envelope, outer mitochondrial membrane and possibly the endoplasmic reticulum (ER). Thus, Bcl-w has a subcellular localization comparable to that of its closest pro-survival relatives, Bcl-2 and $\mathrm{Bcl}-\mathrm{x}_{\mathrm{L}}$.

\section{Results}

\section{Characterization of monoclonal antibodies to Bcl-w}

Monoclonal antibodies recognizing native Bcl-w protein were identified by immunofluorescence staining and flow cytometric analysis as previously described, ${ }^{16}$ using an equal 
mixture of parental FDC-P1 cells and a subline stably expressing EE-tagged Bcl-w. Antibodies specific to Bcl-w were revealed by a double immunofluorescence peak (Figure $1 C, D)$ as seen also by staining with the anti-EE epitope tagspecific antibody (Figure 1B). The peak with lower immunofluorescence intensity represents background immunofluorescence of unstained parental FDC-P1 cells and the higher intensity peak represents specific Bcl-w staining in the stably transfected FDC-P1-EE-Bcl-w cells. Nineteen anti-Bcl-w antibody-secreting clones were expanded and subcloned from an initial screen of 2000 hybridoma cultures.

Two independent mAbs (13F9 and 16H12) that recognize both mouse and human $\mathrm{Bcl}-\mathrm{w}$ and were efficacious in many applications, including immunofluorescence staining, Western blotting and immunoprecipitation (Figure 1E), were chosen for further experiments. Immunoblotting of lysates of 293T cells transiently transfected with expression constructs for different $\mathrm{Bcl}-2$ family members demonstrated that the two mAbs recognized $\mathrm{Bcl}-\mathrm{w}$ but not $\mathrm{Bcl}-2, \mathrm{Bcl}-\mathrm{x}_{\mathrm{L}}$, Bak, Bax, Bad or Bim (Figure $2 \mathrm{~A}-\mathrm{C}$ ). Both mAbs detected the $21 \mathrm{kDa} B c l-w$ protein from tissue lysates of normal mice but not from those of $\mathrm{Bcl}-\mathrm{w}$ deficient mice (Figure 4A,B). Some cross-reactivity was observed on Western blotting but only to two proteins considerably larger than Bcl-w, so this did not preclude their use in expression analysis.
A

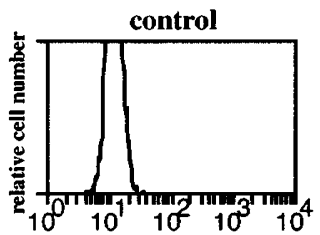

C

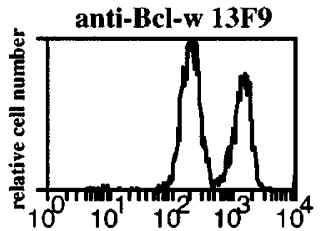

B

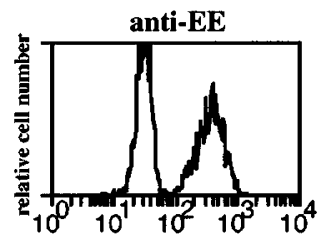

D

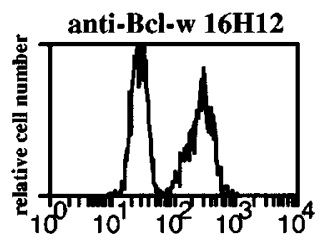

$\mathbf{E}$

\begin{tabular}{cccc}
$\begin{array}{c}\text { Antibody } \\
\text { Clone }\end{array}$ & Isotype & Applications & Species \\
\hline $13 \mathrm{~F} 9$ & IgG2aK & IF, IP, WB & hs, mm, ca, m, cc \\
$16 \mathrm{H} 12$ & IgG2aK & IF, IP, WB & hs, mm, ca, m, cc
\end{tabular}

Figure 1 Screening for Bcl-w specific monoclonal antibodies (mAbs). Parental FDC-P1 cells and a subline stably expressing EE-Bcl-w were mixed at a ratio of $1: 1$, fixed, permeabilized and stained with secondary antibody alone (A, negative control), with anti-EE mAb (B, positive control) or with the anti-Bcl-w mAbs $13 \mathrm{Fg}$ (C) or $16 \mathrm{H} 12$ (D). Staining was visualized by FITCconjugated goat anti-mouse IgG (B) or anti-rat IgG antibodies (A, C, D). (E) Summary of the characteristics of the anti-Bcl-w mAbs $13 \mathrm{~F} 9$ and $16 \mathrm{H} 12$. Both antibodies recognize human (hs), mouse (mm), monkey (ca), rat (rn) and dog (cc) Bcl-w protein by immunofluorescence staining (IF), immunopecipitation (IP) and Western blotting (WB)

\section{Expression of Bcl-w in cell lines and mouse tissues}

Bcl-w expression in cell lines was determined by Western blotting of immunoprecipitates from cell lysates. Examples of such IP/Western blots are shown in Figure 3 and the overall results are summarized in Table 1 . Readily detectable levels of Bcl-w were found in cell lines of myeloid (416B, BAF-3 and FDC-P1), fibroblast (NIH3T3, Rat-1 and L929) and epithelial origin (MCF-7, SW480 and EB-3). Bcl-w protein was not detected in most lymphoid cell lines ( $B$ and $T$ ) and, where it was expressed (e.g. ABLS 8.1, CH1 and SP2/0), the levels were often low. In thymic lymphoma-derived lines Bcl-w expression was only found in cells with a CD4 ${ }^{-} 8^{-}$phenotype (Table 1), representing a very early stage of $T$ cell development.

A broad survey of normal mouse tissues by Western blotting readily detected $\mathrm{Bcl}-\mathrm{w}$ in the brain, spinal cord, colon, testes, pancreas, heart, spleen and mammary glands of pregnant mice (Figure 4A,B). Moderate levels of

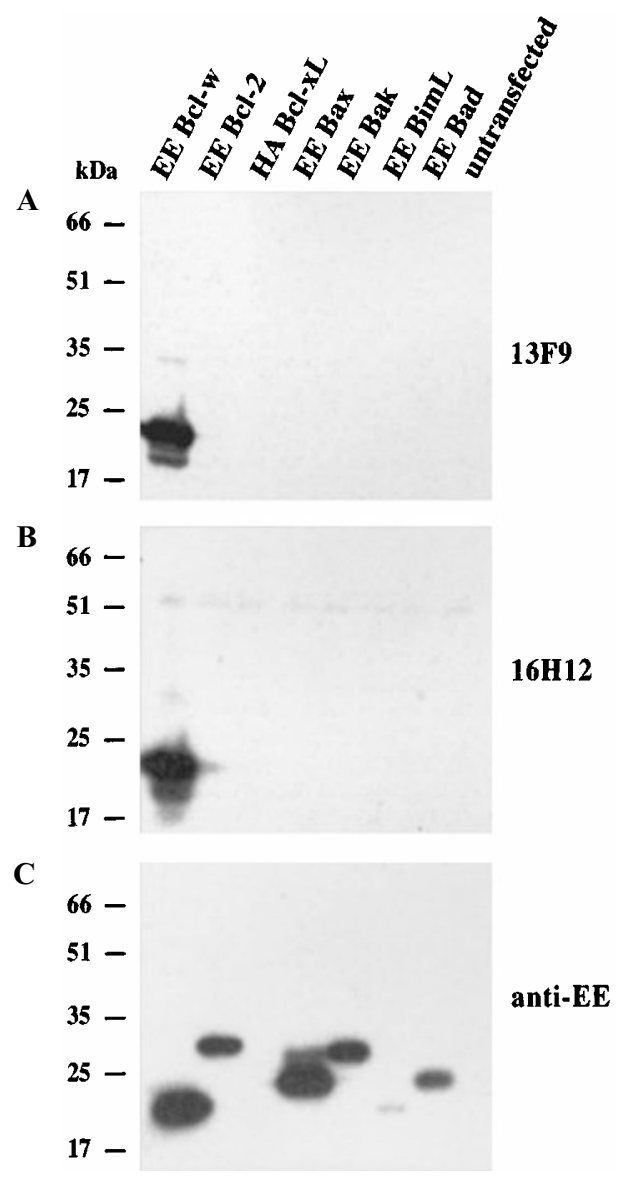

Figure 2 Verification of the specificity of the anti-Bcl-w mAbs 13F9 and 14A8. Lysates from 293T cells transiently transfected with expression constructs encoding EE-tagged Bcl-2 family members Bcl-w, Bim , Bad, Bak, Bax, Bcl-2 or HA-tagged $\mathrm{Bcl}-\mathrm{x}_{\mathrm{L}}$ were immunoblotted with the anti-Bcl-w mAbs $13 \mathrm{~F} 9(\mathbf{A})$, $16 \mathrm{H} 12$ (B) and as a control with anti-EE mAb (C) or anti-HA mAb (not shown). Bound antibodies were revealed by horseradish peroxidase (HRP)-conjugated goat anti-rat Ig or anti-mouse Ig antibodies, followed by ECL detection. Expression levels of $\mathrm{Bim}_{\mathrm{L}}$ are low because it potently induces apoptosis ${ }^{39}$ 


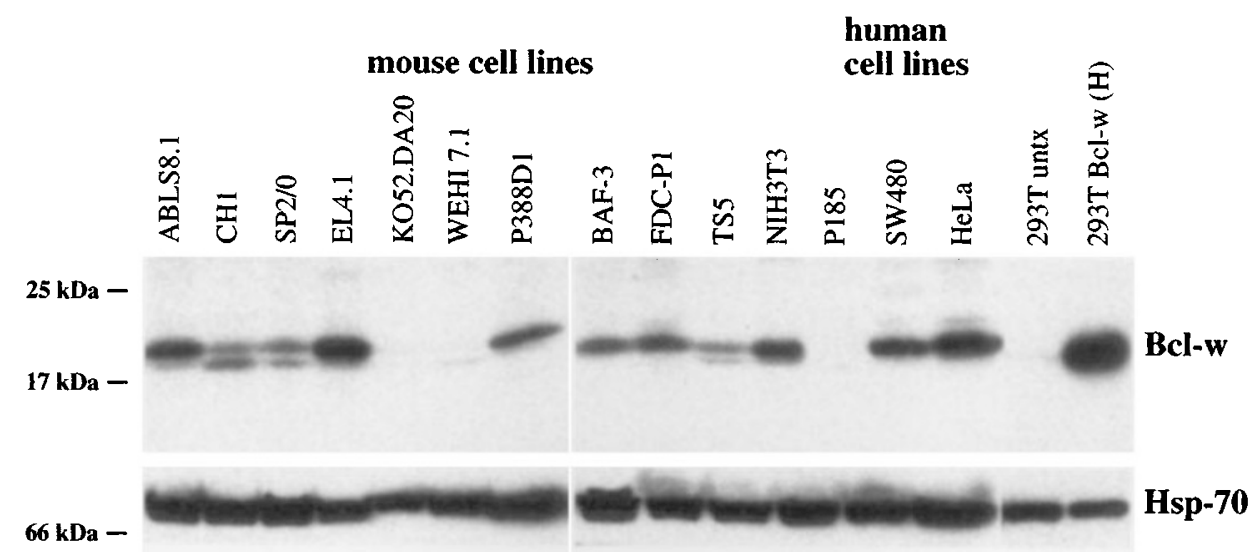

Figure $3 \mathrm{Bcl}-\mathrm{w}$ expression in cultured mouse and human cell lines. Bcl-w protein was revealed in lysates from mouse and human cell lines by Western blotting and detection by ECL

$\mathbf{A}$

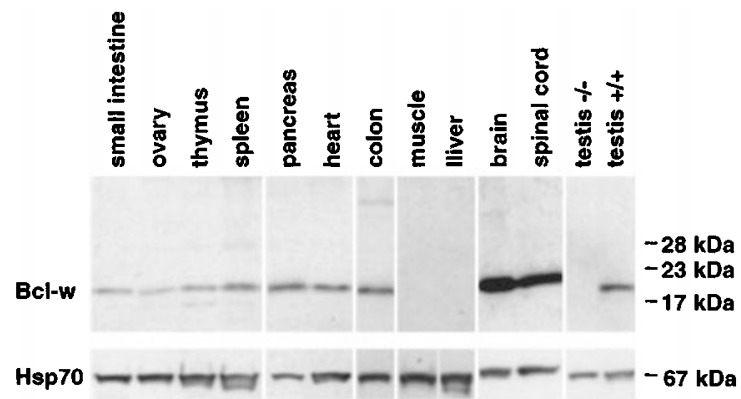

B

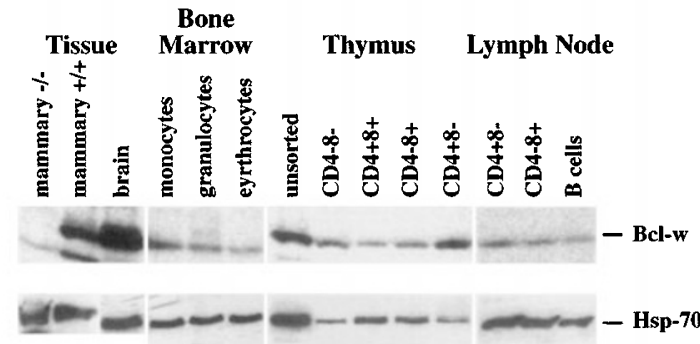

Figure $4 \mathrm{Bcl}-\mathrm{w}$ expression in normal mouse tissues and in purified hematopoietic cell types. Western blot analysis of Bcl-w expression in normal mouse tissues (A) and in sorted lymphoid, myeloid and erythroid cells from bone marrow, thymus and lymph nodes (B). Tissue lysates and lysates of sorted cells were prepared, normalized for total protein content and $30 \mu \mathrm{g}$ of protein were size-fractionated by SDS-PAGE and electroblotted onto nitrocellulose. Immunoblot analysis with $\mathrm{mAb} 16 \mathrm{H} 12$ was performed as described in the legend to Figure 3. Equal protein loading was demonstrated by immunoblotting with a mAb specific to HSP 70

Bcl-w were also found in thymus, ovary and small intestine but no $\mathrm{Bcl}-\mathrm{w}$ expression could be detected in salivary gland (not shown), muscle or liver. Sub-populations of hematopoietic cells from thymus, lymph nodes and bone marrow were isolated by immunofluorescence staining for specific surface markers followed by flow cytometry. Western blotting of cell lysates detected $\mathrm{Bcl}-\mathrm{w}$ in all four major thymocyte sub-populations, mature $B$ and $T$ cells in lymph nodes, and in granulocytes, monocytes and erythroid cells from bone marrow (Figure 4B). Collectively, these results demonstrate that $\mathrm{Bcl}-\mathrm{w}$ is expressed in reproductive organs and in cells of hematopoietic, fibroblastoid, neuronal and epithelial lineages.

\section{Subcellular localization of Bcl-w}

We next wished to compare the subcellular localization of $\mathrm{Bcl}-$ $\mathrm{w}$ with that of its closest homologs, Bcl-2 and Bcl- $\mathrm{x}_{\mathrm{L}}$. Electron and confocal microscopy studies have previously demonstrated that $\mathrm{Bcl}-2$ is located on the cytoplasmic face of the outer mitochondrial membrane, the nuclear envelope and the endoplasmic reticulum ${ }^{17,18}$ and $\mathrm{Bcl}-\mathrm{X}_{\mathrm{L}}$ resides on the outer mitochondrial membrane. ${ }^{19}$ While $\mathrm{Bcl}-2$ is exclusively membrane-bound in subcellular fractionation experiments, a proportion of $\mathrm{Bcl}-\mathrm{x}_{\mathrm{L}}$ is found in the soluble fraction in lysates prepared from healthy cells. After a death stimulus, however, both proteins are present exclusively in the insoluble pellet fraction. ${ }^{20,21}$

To investigate the subcellular localization of $\mathrm{Bcl}-\mathrm{w}$, we chose to mechanically disrupt cells by Dounce homogenization, rather than lysing them with non-ionic detergents which has been shown to cause artefactual changes in localization of $\mathrm{Bcl}-2$ family members. ${ }^{22}$ Subcellular fractions of healthy HeLa cells were analyzed by immunoblotting with mAbs $13 \mathrm{F9}$ and $16 \mathrm{H} 12$ (Figure 5). Most of the Bcl-w protein was associated with the heavy membrane (HM) fraction, as was most of $\mathrm{Bcl}-2$ and $\mathrm{Bcl}-\mathrm{x}_{\mathrm{L}}$. (Under these conditions, the mitochondria and ER are likely to have fractionated in the $\mathrm{HM}$ fraction since their respective markers, VDAC/porin and calnexin, were found exclusively in this fraction.) However, a significant amount of Bcl-w was present in the soluble cytosolic fraction (S), which also contained some Bcl- $x_{\mathrm{L}}$ but negligible amounts of $\mathrm{Bcl}-2$. After UV irradiation (Figure 5) or treatment with staurosporine or etoposide (data not shown), neither Bcl-w nor Bcl$X_{L}$ was present at substantial levels in the soluble fraction. Two explanations could account for the differences in subcellular fractionation of $\mathrm{Bcl}-\mathrm{w}$ and $\mathrm{Bcl}-\mathrm{x}_{\mathrm{L}}$ between healthy cells and cells undergoing apoptosis. A proportion of $\mathrm{Bcl}-\mathrm{w}$ or $\mathrm{Bcl}-\mathrm{x}_{\mathrm{L}}$ might normally be cytosolic and only translocates to intracellular membranes upon induction of 
Table 1 IP/Western analysis of Bcl-w expression in cultured cell lines. Bcl-w expression was determined by IP/Western blotting as described in the legend to Figure 3

\begin{tabular}{|c|c|c|c|}
\hline Cell line & Origin & Species & Bcl-w \\
\hline ABLS 8.1 & pre-B lymphoma & mouse & + \\
\hline $70 Z / 3$ & pre-B lymphoma & mouse & - \\
\hline RAW 8.10 & pre-B lymphoma & mouse & - \\
\hline $\mathrm{CH} 1$ & B lymphoma & mouse & + \\
\hline WEHI 231.1 & B lymphoma & mouse & - \\
\hline WEHI 279.1 & B lymphoma & mouse & - \\
\hline Sp2/0 & plasmacytoma & mouse & + \\
\hline NS-1 & plasmacytoma & mouse & + \\
\hline BW514.7 & T lymphoma CD4-8- & mouse & low+ \\
\hline S49.1 & T lymphoma CD4-8- & mouse & - \\
\hline TIKAUT & T lymphoma CD4-8- & mouse & - \\
\hline WEHI 105.7 & T lymphoma CD4-8- & mouse & low+ \\
\hline $\mathrm{EL}-4.1$ & T lymphoma CD4-8- & mouse & + \\
\hline WEHI 703 & T lymphoma CD4 + 8+ & mouse & - \\
\hline K052 DA.20 & T lymphoma CD4 + 8+ & mouse & - \\
\hline WEHI 7.1 & T lymphoma CD4 + 8+ & mouse & - \\
\hline B6.2.16.BW2 & T cell hybridoma & mouse & + \\
\hline Jurkat & T lymphoma CD4 + 8+ & human & - \\
\hline P388D1 & macrophage & mouse & + \\
\hline J774 & macrophage & mouse & + \\
\hline 34.6Myl & granulocyte & mouse & + \\
\hline RAW 264.7 & macrophage & mouse & + \\
\hline $\mathrm{F} 4 \mathrm{~N}$ & erythroleukaemia & mouse & + \\
\hline TS5 & erythroleukaemia & mouse & + \\
\hline DP16 & erythroleukaemia & mouse & + \\
\hline BAF-3 & myeloid & mouse & + \\
\hline FDC-P1 & myeloid & mouse & + \\
\hline $416 \mathrm{~B}$ & myeloid & mouse & + \\
\hline 416BMEG & megakarocyte & mouse & + \\
\hline P-815X-2.1 & mastocytoma & mouse & - \\
\hline NIH/3T3 & fibroblast & mouse & + \\
\hline Rat1 & fibroblast & rat & + \\
\hline L-929 & fibroblast & mouse & + \\
\hline WEHI 11 & fibrosarcoma & mouse & + \\
\hline MDCK & kidney & dog & + \\
\hline MCF-7 & breast carcinoma & human & + \\
\hline 293T & embryonic kidney & human & + \\
\hline HK-2 & kidney proximal & human & + \\
\hline G-401 & Wilm's tumor (kidney) & human & + \\
\hline TCMK-1 & kidney & mouse & + \\
\hline Cosm6 & kidney (fibroblast) & monkey & + \\
\hline MH134 & hepatoma & mouse & + \\
\hline HepG2 & liver (epithelial) & human & + \\
\hline SW480 & colon carcinoma & human & + \\
\hline EB-3 & colon carcinoma & human & + \\
\hline HeLa & cervical carcinoma & human & + \\
\hline
\end{tabular}

$\sim$ megakaryocyte differentiation induced by GATA-1 expression

apoptosis. Alternatively, these proteins might normally be only weakly attached to intracellular membranes and therefore easily stripped off during fractionation. During apoptosis induction, Bcl-w attachment to cytoplasmic membranes might be strengthened by increased association with other membrane-anchored proteins.

To explore this further, we studied Bcl-w localization by immunofluorescence staining and confocal microscopy. In view of the cross-reactivity of the antibodies to Bcl-w, HeLa cells stably expressing EE-epitope tagged Bcl-w were stained with an anti-EE mAb, which did not produce any non-specific staining, were used for these experiments. Confocal microscopic analysis of three independently derived $\mathrm{Bcl}-\mathrm{w}$-expressing HeLa cell lines showed staining around the nuclear envelope and a punctate cytoplasmic

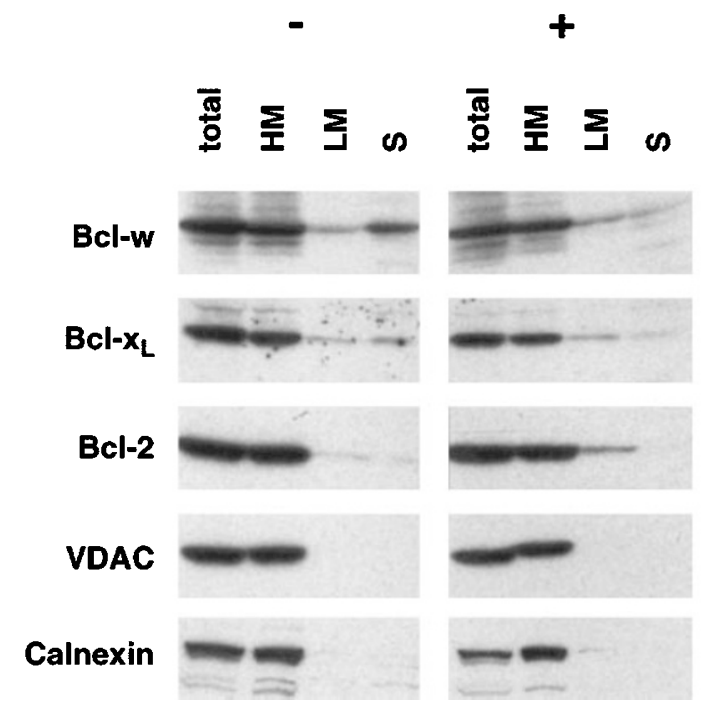

Figure 5 Subcellular localization of endogenous Bcl-w. HeLa cell lysates prepared by Dounce homogenization were separated into heavy membrane $(\mathrm{HM})$, light membrane (LM) and soluble (S) fractions. Proteins in fractions were size-fractionated by SDS-PAGE, electroblotted onto membranes and immunoblotting performed with mAbs specific for the proteins indicated. Bcl-w protein was found in all three fractions in extracts from healthy cells but only in the HM and LM fractions in extracts from cells that had been UV-irradiated $(100 \mathrm{~J} /$ $\left.\mathrm{m}^{2}\right) 6$ h earlier. Data shown are representative of three independent experiments

pattern (Figure 6A-C). Mitotracker Red was used to identify mitochondria. This revealed that most (if not all) cytoplasmic Bcl-w staining is likely to be mitochondrial as there was very substantial overlap with Mitotracker Red staining (Figure 6D-I). We therefore conclude that Bcl-w has a subcellular distribution comparable to its closest homologs, $\mathrm{Bcl}-2^{17}$ and $\mathrm{Bcl}-\mathrm{x}_{\mathrm{L}} \cdot{ }^{21}$

\section{Discussion}

$\mathrm{Bcl}-\mathrm{w}$ like its closest relatives, $\mathrm{Bcl}-2$ and $\mathrm{Bcl}-\mathrm{x}_{\mathrm{L}}$, protects cells against a wide range of apoptotic stimuli, although not those triggered by ligation of 'death receptors'. ${ }^{12}$ Our subcellular fractionation (Figure 5) and confocal microscopy (Figure 6) analyses demonstrated that Bcl-w protein is localized to the nuclear envelope and mitochondria, the same sites where $\mathrm{Bcl}$ 2 and $\mathrm{Bcl}-\mathrm{x}_{\mathrm{L}}$ reside. ${ }^{17-19}$ No significant levels of $\mathrm{Bcl}-\mathrm{w}$ could be detected by confocal microscopy in the cytosol of HeLa cells, even when the protein was overexpressed (Figure 6). Since $\mathrm{Bcl}-\mathrm{w}$ has a hydrophobic $\mathrm{C}$-terminal tail like $\mathrm{Bcl}-2$ and $\mathrm{Bcl}-\mathrm{x}_{\mathrm{L}}$, it is likely that $\mathrm{Bcl}-\mathrm{w}$ is attached to cytoplasmic membranes in a manner similar to those two pro-survival molecules. However, Bcl-w association with cytoplasmic membranes appears to be easily disrupted during subcellular fractionation, since some appears in the soluble fraction (Figure 5), as is the case for Bcl$X_{L}{ }^{20,21}$ (and Figure 5). Interestingly, in cells exposed to an apoptotic stimulus, the attachment of Bcl-w (and Bcl- $\mathrm{x}_{\mathrm{L}}$ ) to membranes appeared to be stronger. The basis for the change in Bcl-w in cells exposed to apoptotic stimuli remains to be determined but may be related to the translocation to cytoplasmic membranes of pro-apoptotic Bcl-2 family members, such as Bax, Bad or Bim. ${ }^{21,23,24}$ 


\section{HeLa EE Bcl-w}

\section{anti-EE}

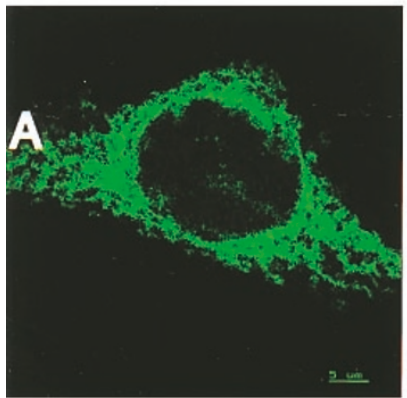

anti-EE

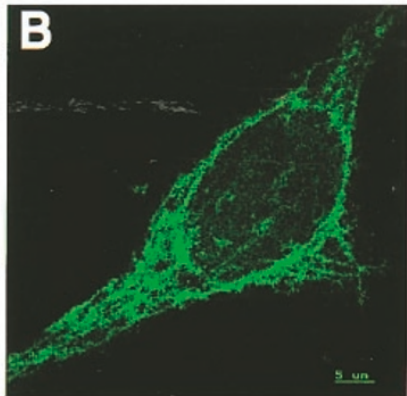

anti-EE

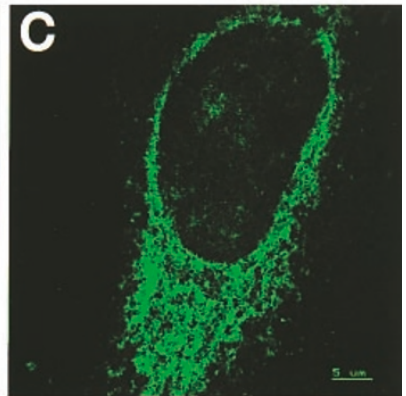

\section{HeLa EE Bcl-w}

\section{anti-EE}

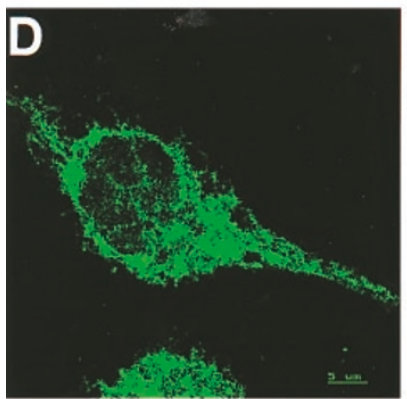

HeLa
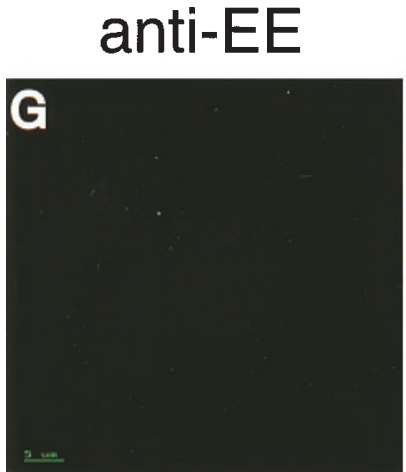

Mito

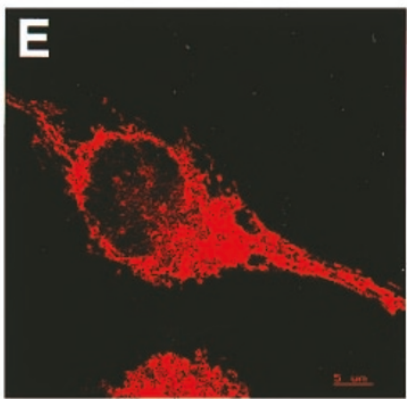

anti-EE + Mito

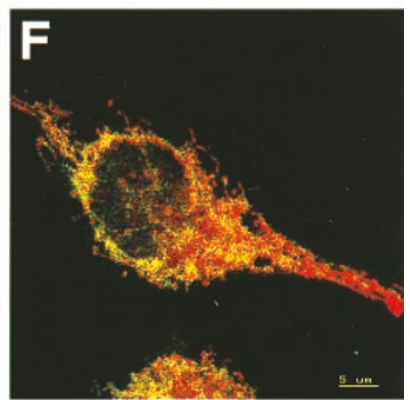

anti-EE + Mito
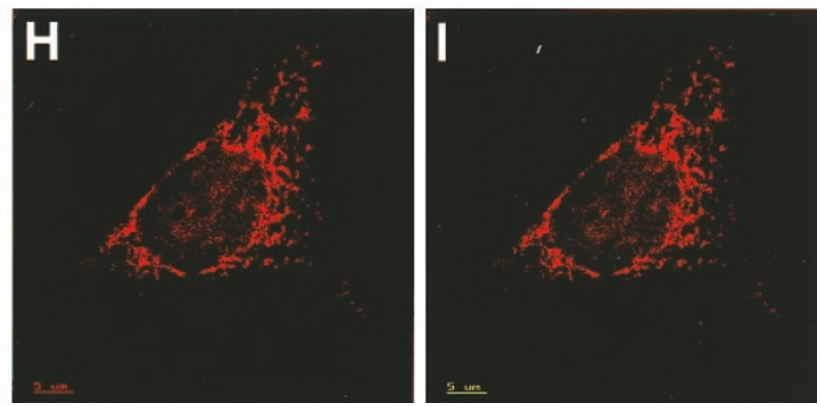

Figure 6 Detection of Bcl-w on the nuclear envelope and mitochondrial membranes by immunofluorescence staining and confocal microscopy. Bcl-w localization in three independent HeLa clones $(\mathbf{A}-\mathbf{C})$ stably expressing EE-Bcl-w was analyzed by immunofluorescence staining with anti-EE mAb and FITC-conjugated goat anti-mouse-Ig antibodies. Data shown are representative of $\geqslant 20$ cells examined. Co-localization of Bcl-w with mitochondria (D-I). HeLa cells expressing EE-Bcl-w (D-F) or parental HeLa cells (G-I) were analyzed by confocal microscopy after staining with anti-EE mAb plus FITC-conjugated anti-mouse IgG antibodies (D, G) and labeling with Mitotracker Red $(\mathbf{E}, \mathbf{H})$. The images were overlaid (F, I) and yellow staining is indicative of localization of Bcl-w on mitochondria. Data shown are representative of three independent EE-Bcl-w HeLa clones. Bars represent $5 \mu \mathrm{m}$

Although $\mathrm{Bcl}-\mathrm{w}$ is functionally and biochemically very similar to $\mathrm{Bcl}-2$ or $\mathrm{Bcl}-\mathrm{x}_{\mathrm{L}}$, their primary physiologic activities differ. Gene targeting experiments in mice have demonstrated that Bcl-w plays a critical role during spermatogenesis but is not obligatory for other developmental processes. $^{14,15}$ In contrast, Bcl-2 is critical for normal development of the kidney, lymphocyte survival and hair growth, ${ }^{25}$ whereas $\mathrm{Bcl}-\mathrm{x}$ is essential for erythropoiesis and neuronal development. ${ }^{26}$ The more distant pro-survival relatives $\mathrm{Mcl}-1$ and $\mathrm{A} 1$ appear to be required for preimplantation development and embryo implantation ${ }^{27}$ and for granulocyte survival, ${ }^{28}$ respectively. Thus, some cell 
types appear to rely (almost) exclusively on one Bcl-2-like protein for survival, whereas others may be protected by several family members due to overlapping expression.

Earlier Northern blot analysis indicated that Bcl-w has a widespread expression pattern. ${ }^{12}$ Using our novel anti-Bcl-w mAbs, we showed that $\mathrm{Bcl}-\mathrm{w}$ is expressed in a range of tissues with high levels detected in the brain, spinal cord, testes, colon and moderate levels found in the heart, pancreas, small intestine, ovary and hematopoietic tissues (Figures 3 and 4). As these organs appeared histologically normal in Bcl-w-deficient mice ${ }^{14,15}$ it appears likely that expression of other anti-apoptotic Bcl-2 family members is sufficient to maintain normal cell survival in these tissues.

A survey of cell lines and primary mouse hematopoietic cells revealed that Bcl-w protein is expressed in lymphocytes, macrophages, granulocytes, megakaryocytes and erythroid cells (Figures 3 and 4). Many other pro-survival $\mathrm{Bcl}-2$ family members are also expressed in hematopoietic cells and some were shown to be essential for their survival. Bcl-2 is required for IL-7R-mediated survival of T cell progenitors ${ }^{29,30}$ and longevity of mature lymphocytes. ${ }^{25}$ $\mathrm{BCl}-\mathrm{x}_{\mathrm{L}}$ expression is induced by EPO-R-mediated Stat5a/b activation $^{31,32}$ and is essential for survival of erythroid cells during embryogenesis. ${ }^{26}$ A1 plays a limited role in granulocyte survival. $^{28}$ Interestingly, mice lacking the $\mathrm{BH} 3-$ only protein Bim have excess lymphocytes, monocytes and granulocytes, ${ }^{33}$ indicating that it is the critical activator of apoptosis in all of these cell types. In spite of the lack of any obvious hematopoietic defect in Bcl-wdeficient mice, Bcl-w may play an auxiliary role in hematopoietic cell survival under certain circumstances. Such functions might be uncovered in mutant animals lacking Bcl-w plus one or several other anti-apoptotic Bcl-2 family members.

The highest levels of Bcl-w were found in the brain of adult mice (Figure 4). Many of the other anti-apoptotic Bcl-2 family members, including $\mathrm{Bcl}-2$ and $\mathrm{Bcl}-\mathrm{x}_{\mathrm{L}}$, are also expressed in the brain. ${ }^{26,34} \mathrm{Bcl}-\mathrm{x}$-deficient mice die around $\mathrm{E} 15$ with massive neuronal apoptosis ${ }^{35}$ demonstrating that $B c l-x_{L}$ is essential for cell survival in the developing central nervous system. It is presently unknown which $\mathrm{Bcl}-2$ family member(s) is (are) required to maintain neuronal survival in adult animals. Although $\mathrm{Bcl}-\mathrm{w}$-deficient mice have no obvious abnormalities in the nervous system, ${ }^{14,15} \mathrm{Bcl}-\mathrm{w}$ might have a neuroprotective function under conditions of stress. Consistent with this idea it has been observed that Bcl-w expression is increased in ischaemic regions of the rat brain. ${ }^{35}$

$\mathrm{Bcl}-\mathrm{w}$ expression was also found in several tumor-derived cell lines of epithelial origin (Figure 3 ) and in mouse tissues that are rich in epithelial cells (Figure 4). Tissues of epithelial origin are therefore another cell type in which Bcl-w may play a role in inhibiting apoptosis. Neither untreated $\mathrm{Bcl}-\mathrm{w}-$ deficient mice nor any of the other mutant animals lacking individual anti-apoptotic Bcl-2 family members have known abnormalities in the gastrointestinal tract. It is therefore possible that under normal physiologic circumstances, specific defects in these tissues may only be manifest in mice lacking two or several anti-apoptotic Bcl-2 family members. However, recent studies have shown that gut epithelial cells from $\mathrm{Bcl}-\mathrm{w}$-deficient mice are abnormally sensitive to $\gamma$-irradiation or treatment with the cytotoxic drug 5-fluorouracil. ${ }^{36}$ Moreover, Bcl-w levels are increased in epithelial cells adjacent to resected gut segments, ${ }^{37}$ indicating that $\mathrm{Bcl}-\mathrm{w}$ might protect against stress in this scenario. Interestingly, many human colon cancers express strikingly high levels of $\mathrm{Bcl}-\mathrm{w}^{38}$ (Figure 3 and Table 1). Hence, Bcl-w may play a role in the pathogenesis of colonic tumors. It will therefore be interesting to investigate whether $\mathrm{Bcl}$-w-deficiency affects tumor incidence or latency in mutant mouse strains that are predisposed to colon cancer, such as the min mice which lack the APC tumor suppressor.

In conclusion, our expression analyses identify a range of tissues, besides the testes, in which Bcl-w might play a role in blocking apoptosis.

\section{Materials and Methods}

\section{Experimental animals}

All experiments with animals were performed according to the guidelines of the Royal Melbourne Hospital Research Foundation Animal Ethics Committee. Wistar rats and C57BL/6 mice were obtained from our Institute's breeding facility.

\section{Expression constructs and protein purification}

Epitope (EE- or HA-tagged) expression vectors for Bcl-w, Bcl-2, Bcl$X_{L}, B a x, B a k, B i m$ and Bad have been previously described ${ }^{39,40}$ or were generated by subcloning into derivatives of pEF PGKpuro or pEF PGKhygro vectors, incorporating the N-terminal EE (EYMPME) ${ }^{41}$ or HA (YPYDVPDYA) ${ }^{42}$ epitope tags. All constructs were verified by automated sequencing ( $A B \mathrm{BI}$ Perkin Elmer). The vector pQE-9 Bcl-w was constructed by subcloning the full-length human $b c /-w$ gene inframe with the N-terminal (His) 6 tag in $\mathrm{PQE}-9$ (Qiagen). Recombinant (His) ${ }_{6}$-tagged Bcl-w protein was produced in SG13009 [PREP 4] cells and purified on a nickel column according to the manufacturer's protocols (Qiagen).

\section{Immunization, hybridoma fusion and screening for antibodies to $\mathrm{Bcl}-\mathrm{w}$}

Wistar rats were initially immunized by subcutaneous (s.c.) injection with $100 \mu \mathrm{g}$ purified recombinant human Bcl-w protein dissolved in complete Freund's adjuvant (Difco). Two subsequent boosts of the immunogen, resuspended in incomplete Freund's adjuvant (Difco), were injected s.c. 3 and 6 weeks later. A final boost with Bcl-w protein dissolved in PBS was given intravenously (i.v.) and i.p. 4 weeks after this. Three days later, hybridomas were generated by fusing spleen cells from immunized rats with the SP2/0 myeloma cell line as previously described. ${ }^{16,43}$ Hybridomas producing monoclonal antibodies to $\mathrm{Bcl}-\mathrm{w}$ were identified and their isotype determined using a screening strategy that we have previously described. ${ }^{16}$ Briefly, parental FDC-P1 cells and a subclone stably expressing EE-tagged mouse or human $\mathrm{Bcl}-\mathrm{w}$ were mixed at a $1: 1$ ratio, fixed in $1 \%$ paraformaldehyde, permeabilized with $0.3 \%$ saponin (Sigma) and stained with hybridoma supernatants. Bound antibodies were revealed with fluorescein-isothyocyanate (FITC)-conjugated goat anti-rat $\mathrm{lg}$ antibodies (Southern Biotechnology) and analyzed in a FACScan analyzer (Becton Dickinson). Hybridomas producing antibodies to $\mathrm{Bcl}-\mathrm{w}$ were cloned twice and adapted for growth in medium containing low serum. For production of large amounts of antibodies, hybridomas 
were cultured for several weeks in the miniPERM classic $12.5 \mathrm{kDa}$ production and nutrient module (Heraeus). Antibodies were purified on a protein-G sepharose column (Pharmacia).

\section{Cell lines, tissue culture and transfection with expression constructs}

The cell lines used for analysis of $\mathrm{Bcl}-\mathrm{w}$ expression are indicated in Table 1. Details of these cell lines are available from the authors. The cells were cultured in the high glucose version of Dulbecco's modified Eagle's medium (DMEM) supplemented with 10\% fetal calf serum (FCS), $50 \mu \mathrm{M}$ 2-mercaptoethanol (2-ME), $13 \mu \mathrm{M}$ folic acid and $100 \mu \mathrm{M}$ $\mathrm{L}$-asparagine, or were grown in DME or RPMI medium with $10 \% \mathrm{FCS}$. Cultures of parental FDC-P1 and BAF-3 cells and their derivatives were supplemented with IL-3 $(1000 \mathrm{U} / \mathrm{ml})$. FDC-P1 clones stably expressing EE-tagged mouse or human Bcl-w were generated by transfection with expression vectors for these proteins and selection with hygromycin. Liposome (Lipofectamine, Gibco BRL) mediated transfection of 293T and HeLa cells was performed as previously described. ${ }^{44}$ To generate HeLa lines stably overexpressing Bcl-w, cells were transfected with a pEF EE-human Bcl-w PGKhygro vector and were plated at limiting dilution in the presence of $1 \mathrm{mg} / \mathrm{m}$ hygromycin. Clones expressing high levels of $\mathrm{Bcl}-\mathrm{w}$ were identified by cytoplasmic immunofluorescence staining and flow cytometric analysis. ${ }^{13}$ Apoptosis was induced in HeLa cells by UV irradiation $\left(100 \mathrm{~J} / \mathrm{m}^{2}\right)$.

\section{Immunofluorescence staining and cell sorting}

Surface immunofluorescence staining of thymocytes, bone marrow and lymph node cells was performed with cell surface marker-specific monoclonal antibodies as described previously. ${ }^{4,45}$ Antibodies used included RB6-8C5 anti-Gr-1, TER119 anti-erythroid cell-specific surface marker, RA3-6B2 anti-CD45R(B220), GK 1.5 anti-CD4, YTS169 anti-CD8 and M1/70 anti-Mac-1. These antibodies were purified on protein $\mathrm{G}$ sepharose and conjugated to FITC, Rphycoerythrin (R-PE), Cy-5 or biotin (Caltag). Viable cells, not stained by propidium iodide (PI, Sigma), were sorted on the basis of cell surface marker expression on a modified FACSII or a FACStar ${ }^{+}$ (Becton Dickinson).

\section{Immunoprecipitation and Western blotting}

Primary cells, cell lines or transfected 293T cells were harvested, washed twice in cold PBS and lysed in lysis buffer $(20 \mathrm{mM} \mathrm{Tris} / \mathrm{HCl}$, pH 8.0, $125 \mathrm{mM} \mathrm{NaCl}, 1 \mathrm{mM}$ EGTA, 1\% Triton X-100, 10\% glycerol, $0.5 \mu \mathrm{g} / \mathrm{ml}$ Pefabloc, $1 \mu \mathrm{g} / \mathrm{ml}$ of each of leupeptin, aprotinin, soybean trypsin inhibitor and pepstatin, $5 \mathrm{mM} \mathrm{NaF}$ and $2 \mathrm{mM} \mathrm{Na}_{3} \mathrm{VO}_{4}$; all reagents from Sigma or Roche Diagnostics). For preparation of tissue lysates, organs were excised, washed in PBS, immediately frozen in isopentane on dry ice, and were later homogenized at $4^{\circ} \mathrm{C}$ in lysis buffer as detailed in. ${ }^{14}$

Immunoprecipitation was performed according to previously published protocols. ${ }^{46}$ Lysates (from $10^{7}$ cells) were pre-cleared by a $2 \mathrm{~h}$ incubation at $4{ }^{\circ} \mathrm{C}$ with a control $\mathrm{mAb}$ and protein $\mathrm{G}$ sepharose before immunoprecipitating with anti-Bcl-w mAbs plus protein $G$ sepharose for $1.5 \mathrm{~h}$. After extensive washing (six times in lysis buffer), the immunoprecipitated material was eluted by boiling in SDS-PAGE gel loading buffer, size-fractionated on polyacrylamide gels (Novex) and transferred to nitrocellulose membranes (Amersham Pharmacia) by electroblotting. For Western blotting (without prior immunoprecipitation) tissue lysates and lysates of sorted cells were prepared, normalized for total protein content and $30 \mu \mathrm{g}$ of protein size- fractionated by SDS-PAGE and electroblotted onto nitrocellulose membranes. Prior to immunoblotting non-specific binding of antibodies to membranes was blocked by incubation overnight in 5\% skimmed milk, $1 \%$ casein, $0.05 \%$ Tween- 20 . Membranes were then probed with $13 \mathrm{~F} 9$ or $16 \mathrm{H} 12$ anti-Bcl-w mAbs $(2 \mu \mathrm{g} / \mathrm{ml})$ followed by goat anti-rat lgG antibodies conjugated to HRP (Southern Biotechnology) and detection by enhanced chemiluminescence (ECL; Amersham Pharmacia). To control for the concentration and integrity of proteins in the tissue lysates, blots were probed with mouse anti-HSP70 mAb N6 (a gift from Dr R Anderson, Peter MacCallum Cancer Institute, Melbourne, Australia) followed by HRP-conjugated sheep anti-mouse Ig antibodies (Silenus) and detection by ECL.

\section{Subcellular fractionation}

HeLa cells were resuspended in HMKEE buffer $(20 \mathrm{mM}$ HEPES $\mathrm{pH} 7.2,5 \mathrm{mM} \mathrm{MgCl}, 10 \mathrm{mM} \mathrm{KCl}, 1 \mathrm{mM}$ EDTA, $1 \mathrm{mM}$ EGTA, $250 \mathrm{mM}$ sucrose buffer and protease inhibitors) and allowed to swell on ice for $10 \mathrm{~min}$ at $4^{\circ} \mathrm{C}$. Cells were lysed using a Dounce homogenizer (100 strokes with a type 'B' pestle; Konte Glassware Corporation) or by 50 passages through a $27 G$ needle. ${ }^{20}$ After centrifugation at $900 \times g$ at $4^{\circ} \mathrm{C}$ for $5 \mathrm{~min}$ to pellet nuclei and cell debris, the heavy membrane fraction (HM) was resuspended in HMKEE/sucrose. The resulting supernatant was centrifuged at $100000 \times g$ for $1 \mathrm{~h}$ (65 000 r.p.m. for $60 \mathrm{~min}$ in a TLA 100.3 Beckman benchtop rotor) to generate the soluble (S) and light membrane (LM) fractions. The pellet was resuspended in RIPA buffer $(150 \mathrm{mM} \mathrm{NaCl}, 1 \%$ Triton X-100, 0.5\% deoxcholic acid, $50 \mathrm{mM}$ Tris- $\mathrm{HCl} \mathrm{pH} 8.0$ plus protease inhibitors). Lysates from equivalent numbers of cells were analyzed by immunoblotting with the rat anti-Bcl-w mAbs $13 \mathrm{~F} 11$ and $16 \mathrm{H} 12$, polyclonal rabbit anti$\mathrm{Bcl}-\mathrm{x}$ antibodies (Pharmingen) and the mouse mAbs antiporin/ VDAC (Calbiochem-Novabiochem Corp), anti-human Bcl-2 (Bcl-2100 ) and anti-calnexin (Affinity Bioreagents Inc). Bound antibodies were revealed with $\mathrm{HRP}$-conjugated secondary reagents and $\mathrm{ECL}$ detection.

\section{Immunofluorescence staining and confocal microscopy}

To stain for Bcl-w, HeLa cells stably expressing EE-tagged human Bclw were grown in chamber slides (Becton Dickinson). Cells were attached using Cell Tak (Becton Dickinson), fixed with PBS $/ 4 \%$ paraformaldehyde $\mathrm{pH} 10.0$ for $45 \mathrm{~min}$ at room temperature ${ }^{47}$ and permeabilized with $0.5 \%$ Triton $\mathrm{X}-100$. The fixed cells were stained for $1 \mathrm{~h}$ at room temp with the primary mAb, mouse anti-EE (Babco), washed with $0.2 \%$ Tween-20 in PBS and then incubated with FITCconjugated goat anti-mouse Ig antibodies (Southern Biotechnology). Slides were mounted in fluorescent mounting medium (Dako) containing $100 \mu \mathrm{g} / \mathrm{ml}$ DIABCO (Sigma). Controls included staining with the primary or secondary antibodies alone and staining of parental HeLa cells. To stain for mitochondria, cells were incubated at $37^{\circ} \mathrm{C}$ for 15 min with $500 \mathrm{nM}$ Mito Tracker Red (Molecular Probes). Samples were analyzed with a Leica confocal scanning microscope using SCANware software (Leica Lasertechnik).

\section{Acknowledgements}

We thank $\mathrm{L}$ Cullen and S Novakovic for expert technical assistance, $\mathrm{W}$ Carter, K Davern, K Mackwell, K Wycherley for advice with immunization and hybridoma fusion, Dr F Battye, D Kaminaris, J Parker, V Lapatis and C Tarlinton for assistance with flow cytometry and confocal microscopy 
and A Milligan and J Merryfull for animal care. We are grateful to Prof. J Adams for helpful discussions and critical reading of this manuscript. This work was supported by grants and fellowships from the Japan Science and Technology Corporation, AMRAD Biotech, the Leukemia and Lymphoma Society of America (New York) the Anti-Cancer Council of Victoria (Melbourne, Australia), the Dr Josef Steiner Cancer Research Foundation (Bern, Switzerland), the National Health and Medical Research Council (Canberra, Australia; Reg. Key 973002), the Cancer Research Institute (New York) (CA80188) and the NIH.

\section{References}

1. Vaux DL, Haecker G and Strasser A (1994) An evolutionary perspective on apoptosis. Cell 76: 777-779

2. Jacobson MD, Weil M and Raff MC (1997) Programmed cell death in animal development. Cell 88: 347-354

3. Strasser A, Harris AW, Bath ML and Cory S (1990) Novel primitive lymphoid tumours induced in transgenic mice by cooperation between myc and $b c /-2$. Nature 348: $331-333$

4. Strasser A, Whittingham S, Vaux DL, Bath ML, Adams JM, Cory S and Harris AW (1991) Enforced BCL2 expression in B-lymphoid cells prolongs antibody responses and elicits autoimmune disease. Proc. Natl. Acad. Sci. USA 88: $8661-8665$

5. Watanabe-Fukunaga R, Brannan $\mathrm{Cl}$, Copeland NG, Jenkins NA and Nagata S (1992) Lymphoproliferation disorder in mice explained by defects in Fas antigen that mediates apoptosis. Nature 356: $314-317$

6. Barr PJ and Tomei LD (1994) Apoptosis and its role in human disease. Biotechnology 12: $487-493$

7. Thornberry NA and Lazebnik Y (1998) Caspases: enemies within. Science 281 $1312-1316$

8. Strasser A, O'Connor L and Dixit VM (2000) Apoptosis signaling. Annu. Rev. Biochem. 69: 217-245

9. Adams JM and Cory S (1998) The Bcl-2 protein family: arbiters of cell survival. Science 281: $1322-1326$

10. Gross A, McDonnell JM and Korsmeyer SJ (1999) Bcl-2 family members and the mitochondria in apoptosis. Genes Dev. 13: 1899-1911

11. Sattler M, Liang H, Nettesheim D, Meadows RP, Harlan JE, Eberstadt M, Yoon HS, Shuker SB, Chang BS, Minn AJ, Thompson CB and Fesik SW (1997) Structure of $\mathrm{Bcl}-\mathrm{x}_{\mathrm{L}}-\mathrm{Bak}$ peptide complex: recognition between regulators of apoptosis. Science 275: 983-986

12. Gibson L, Holmgreen S, Huang DCS, Bernard O, Copeland NG, Jenkins NA, Sutherland GR, Baker E, Adams JM and Cory S (1996) bcl-w, a novel member of the $b c l-2$ family, promotes cell survival. Oncogene 13: 665-675

13. Strasser A, Harris AW, Huang DCS, Krammer PH and Cory S (1995) Bcl-2 and Fas/APO-1 regulate distinct pathways to lymphocyte apoptosis. EMBO J. 14: 6136-6147

14. Print CG, Loveland KL, Gibson L, Meehan T, Stylianou A, Wreford N, de Kretser D, Metcalf D, Köntgen F, Adams JM and Cory S (1998) Apoptosis regulator Bcl-w is essential for spermatogenesis but appears otherwise redundant. Proc. Natl. Acad. Sci. USA 95: 12424-12431

15. Ross AJ, Waymire KG, Moss JE, Parlow AF, Skinner MK, Russell LD and MacGregor GR (1998) Testicular degeneration in Bclw-deficient mice. Nat. Genet. 18: 251-256

16. O'Reilly LA, Cullen L, Moriishi K, O'Connor L, Huang DCS and Strasser A (1998) Rapid hybridoma screening method for the identification of monoclonal antibodies to low abundance cytoplasmic proteins. BioTechniques 25: $824-830$

17. Lithgow T, van Driel R, Bertram JF and Strasser A (1994) The protein product of the oncogene $b c l-2$ is a component of the nuclear envelope, the endoplasmic reticulum and the outer mitochondrial membrane. Cell Growth Differ. 5:411-417

18. de Jong D, Prins FA, Mason DY, Reed JC, van Ommen GB and Kluin PM (1994) Subcellular localization of the bcl-2 protein in malignant and normal lymphoid cells. Cancer Res. 54: 256-260

19. Gonzalez-Garcia M, Perez-Ballestero R, Ding L, Duan L, Boise LH, Thompson CB and Nuñez $G$ (1994) bcl- $X_{L}$ is the major bcl-x mRNA form expressed during murine development and its product localizes to mitochondria. Development 120: $3033-3042$
20. Hausmann G, O'Reilly LA, van Driel R, Beaumont JG, Strasser A, Adams JM and Huang DCS (2000) Pro-apoptotic apoptosis protease-activating Factor 1 (Apaf1) has a cytoplasmic localization distinct from $\mathrm{Bcl}-2$ or Bcl- $\mathrm{x}_{\mathrm{L}}$. J. Cell. Biol. 149: $623-634$

21. Hsu Y-T, Wolter KG and Youle RJ (1997) Cytosol-to-membrane redistribution of Bax and $\mathrm{Bcl}-\mathrm{X}_{\mathrm{L}}$ during apoptosis. Proc. Natl. Acad. Sci. USA 94: 3668-3672

22. Hsu YT and Youle RJ (1997) Nonionic detergents induce dimerization among members of the Bcl-2 family. J. Biol. Chem. 272: 13829-13834

23. Zha J, Harada H, Yang E, Jockel J and Korsmeyer SJ (1996) Serine phosphorylation of death agonist $B A D$ in response to survival factor results in binding to 14-3-3 not Bcl- $x_{L}$. Cell 87: 619-628

24. Puthalakath H, Huang DCS, O'Reilly LA, King SM and Strasser A(1999) The proapoptotic activity of the $\mathrm{Bcl}-2$ family member Bim is regulated by interaction with the dynein motor complex. Mol. Cell 3: 287-296

25. Veis DJ, Sorenson CM, Shutter JR and Korsmeyer SJ (1993) Bcl-2-deficient mice demonstrate fulminant lymphoid apoptosis, polycystic kidneys, and hypopigmented hair. Cell 75: 229-240

26. Motoyama N, Wang FP, Roth KA, Sawa H, Nakayama K, Nakayama K, Negishi I, Senju S, Zhang Q, Fujii S and Loh DY (1995) Massive cell death of immature hematopoietic cells and neurons in Bcl-x deficient mice. Science 267: 1506 1510

27. Rinkenberger JL, Horning S, Klocke B, Roth K and Korsmeyer SJ (2000) Mcl-1 deficiency results in peri-implantation embryonic lethality. Genes Dev. 14:2327

28. Hamasaki A, Sendo F, Nakayama K, Ishida N, Negishi I, Nakayama K-I and Hatakeyama S (1998) Accelerated neutrophil apoptosis in mice lacking A1-a, a subtype of the bcl-2-related A1 gene. J. Exp. Med. 188: 1985-1992

29. Maraskovsky E, O'Reilly LA, Teepe M, Corcoran LM, Peschon JJ and Strasser A (1997) Bcl-2 can rescue T lymphocyte development in interleukin-7 receptordeficient mice but not in mutant rag-1 ${ }^{-1-}$ mice. Cell 89: 1011-1019

30. AkashiK, Kondo M, von Freeden-JeffryU, Murray RandWeissman IL (1997) Bcl2 rescues $\mathrm{T}$ lymphopoiesis in interleukin-7 receptor-deficient mice. Cell 89: $1033-1041$

31. Silva M, Benito A, Sanz C, Prosper F, Ekhterae D, Nuñez G and Fernandez-Luna $\mathrm{JL}$ (1999) Erythropoietin can induce the expression of Bcl- $x_{\mathrm{L}}$ through Stat5 in erythropoietin-dependent progenitor cell lines. J. Biol. Chem. 274: 2216522169

32. Socolovsky M, Fallon AE, Wang S, Brugnara C and Lodish HF (1999) Fetal anemia and apoptosis of red cell progenitors in Stat5 $\mathrm{a}^{-1-} 5 \mathrm{~b}^{-1-}$ mice: a direct role for Stat5 in Bcl- $X_{L}$ induction. Cell 98: 181-191

33. Bouillet $P$, Metcalf D, Huang DCS, Tarlinton DM, Kay TWH, Köntgen F, Adams JM and Strasser A (1999) Proapoptotic Bcl-2 relative Bim required for certain apoptotic responses, leukocyte homeostasis, and to preclude autoimmunity. Science 286: $1735-1738$

34. Merry DE, Veis DJ, Hickey WF and Korsmeyer SJ (1994) bcl-2 protein expression is widespread in the developing nervous system and retained in the adult PNS. Development 120: 301-311

35. Minami M, Jin KL, Li W, Nagayama T, Henshall DC and Simon RP (2000) Bcl-w expression is increased in brain regions affected by focal cerebral ischemia in the rat. Neurosci. Lett. 279: 193-195

36. Pritchard DM, Print C, O'Reilly L, Adams JM, Potten CS and Hickman JA (2000) $\mathrm{Bcl}-\mathrm{w}$ is an important determinant of damage-induced apoptosis in epithelia of small and large intestine. Oncogene 19: 3955-3959

37. Stern LE, Falcone Jr RA, Kemp CJ, Stuart LA, Erwin CR and Warner BW (2000) Effect of massive small bowel resection on the Bax/Bcl-w ratio and enterocyte apoptosis. J. Gastrointest. Surg. 4: 93-100

38. Wilson JW, Nostro MC, Balzi M, Faraoni P, Cianchi F, Becciolini A and Potten CS (2000) Bcl-w expression in colorectal adenocarcinoma. Br. J. Cancer 82: 178 185

39. O'Connor L, Strasser A, O'Reilly LA, Hausmann G, Adams JM, Cory S and Huang DCS (1998) Bim: a novel member of the Bcl-2 family that promotes apoptosis. EMBO J. 17: 384-395

40. Huang DCS, Cory S and Strasser A (1997) Bcl-2, Bcl- $X_{L}$ and adenovirus protein E1B19 $\mathrm{kD}$ are functionally equivalent in their ability to inhibit cell death. Oncogene 14: 405-414

41. Grussenmeyer T, Scheidtmann KH, Hutchinson MA, Eckhart W and Walter G (1985) Complexes of polyoma virus medium $T$ antigen and cellular proteins. Proc. Natl. Acad. Sci. USA 82: 7952-7954 
42. Wilson IA, Niman HL, Houghten RA, Cherenson AR, Connolly ML and Lerner RA (1984) The structure of an antigenic determinant in a protein. Cell 37: 767-778

43. Galfre G, Howe SC, Milstein C, Butcher GW and Howard JC (1977) Antibodies to major histocompatibility antigens produced by hybrid cell lines. Nature 266 : $550-552$

44. Huang DCS, O'Reilly LA, Strasser A and Cory S (1997) The anti-apoptosis function of $\mathrm{Bcl}-2$ can be genetically separated from its inhibitory effect on cel cycle entry. EMBO J. 16: $4628-4638$
45. Strasser A, Harris AW and Cory S (1991) Bcl-2transgene inhibits T cell death and perturbs thymic self-censorship. Cell 67: 889-899

46. Moriishi K, Huang DCS, Cory S and Adams JM (1999) Bcl-2 family members do not inhibit apoptosis by binding the caspase-activator Apaf-1. Proc. Natl. Acad. Sci. USA 96: 9683-9688

47. BasyukE, Bertrand $E$ and Journot $L$ (2000) Alkaline fixation drastically improves the signal of in situ hybridization. Nucleic Acids Res. 28: E46 